Available Online at SAINS TANAH Website: http://jurnal.uns.ac.id/tanah

SAINS TANAH - Journal of Soil Science and Agroclimatology, 15(2), 2018, 115-122

RESEARCH ARTICLE

\title{
THE EFFECTS OF INORGANIC FERTILIZER AND MINERAL LEUCITE RESIDUES ON K UPTAKE AND MAIZE YIELDS (Zea mays L.) IN OXISOLS
}

\author{
Sri Hartati ${ }^{1 *}$, Slamet Minardi ${ }^{1}$, Wiwik Hartatik ${ }^{2}$, and Isna Luthfa Haniati ${ }^{3}$ \\ ${ }^{1}$ Soil Science Department, Faculty of Agriculture, Sebelas Maret University, Indonesia \\ ${ }^{2}$ Researchers at the Research Institute for Soil, Bogor, Indonesia \\ ${ }^{3}$ Undergraduate Student of Agrotechnology Department, Faculty of Agriculture, Sebelas Maret \\ University, Indonesia
}

Submitted: 2018-03-05 Accepted: 2018-12-08

\begin{abstract}
The purpose of this study was to determine the effect of inorganic fertilizer and leucite mineral residues on $\mathrm{K}$ uptake and maize yields. This research had been conducted from October 2016 to September 2017 in the experimental field of Neglasari, Dramaga, Bogor. The soil was analyzed in the Soil Chemistry and Fertility Laboratory of Sebelas Maret University, Surakarta. The study was arranged in a completely randomized block design using 11 treatments with three replications. The result showed that the NPK $150 \mathrm{~kg} \mathrm{ha}^{-1}$ residues gave a better effect on corn yields whereas there was no significant effect of employing the standard NPK with RAE value of $123 \%$. The study found that the residual treatment of inorganic fertilizers and leucite minerals had a significant impact on maize yields but not on $\mathrm{K}$ uptake.
\end{abstract}

Keyword: Potassium, Mineral Leucite, NPK Formulation, K Uptake, Maize Yields.

How to Cite: Hartati, S., Minardi, S., Hartati, W., and Haniati, I.L. (2018). The Effects of Inorganic Fertilizer and Mineral Leucite Residues on K Uptake and Maize Yields (Zea mays L.) In Oxisols. Sains Tanah Journal of Soil Science and Agroclimatology, 15(2): 115-122 (doi: 10.15608/stjssa.v15i2.18604)

Permalink/DOI: http://dx.doi.org/10.15608/stjssa.v15i2.18604

\section{INTRODUCTION}

Corn is an agricultural commodity that received special attention in Indonesia after rice (Setiawan \& Basri, 2017). Data and Information System of Agriculture said that corn production in 2015 increased to 19.61 million tonnes from 19.01 million tonnes in 2014. The increase in corn production will be followed by the increasing demand of

\footnotetext{
* Corresponding Author :
} Email: srihartati59@staff.uns.ac.id fertilizers because there is a limited capability of soil in supplying nutrients to the corn plant. This becomes a concern since fertilization is considered to be one of the important ways to provide nutrients needed by plants (Yousaf et al., 2017); leading to the increasing amount of corn yields (Prahasta, 2009). In this regard, there are macronutrients essential for the productivity of corn including $\mathrm{N}, \mathrm{P}$, and $\mathrm{K}$ (Nurdin et al., 2009). It should also be noted that the deficiency of potassium will lead to the low production of corn (Du et al., 2017). The 
availability of potassium in the plant is highly varied, due to its complexity and dynamics, which are strongly influenced by the interaction of roots and soil. Potassium plays significant roles in enhancing the quality of crops like improving the physical performance, disease resistance, and post-harvest performance of fruits and vegetables for human consumption (Prajapati \& Modi, 2012). One of the sources of potassium is mineral leucite consisting of potassium and aluminium tectosilicate $\mathrm{K}\left[\mathrm{AlSi}_{2} \mathrm{O}_{6}\right]$ (Turner 2009). The addition of leucite mineral is able to increase potassium in the soil so the availability of potassium can be increased and optimally absorbed by the plant (Irawati et al., 2017).

The effort to increase the production of corn in Indonesia can be supported by employing the alternative raw materials of $\mathrm{K}$ fertilizers such as leucite minerals that have medium to high K nutrients (Manning, 2010). However, although no one disagrees of the significant role of fertilizers in promoting the increase of crop yields, it is a fact that there is still a shortage of mineral resources used as the materials of composing $\mathrm{K}$ potash fertilizer, which is usually fulfilled through importing from the other countries.

\section{MATERIALS AND METHOD}

This research had been conducted from October 2016 until September 2017 in the experimental field of Neglasari, Dramaga, Bogor. The soil analysis was carried out in the Soil Chemistry and Fertility Laboratory of Sebelas Maret University, Surakarta. The soil used in this experiment was Oxisols, containing
$41 \%$ sand, $26 \%$ silt, and $33 \%$ clay. The fields have a very acidic $\mathrm{pH}$ (4.49) caused by high base leaching and relatively medium $\mathrm{Al}-\mathrm{KCl}$ (1.94 me $\left.100 \mathrm{~g}^{-1}\right) \cdot \mathrm{K}_{2} \mathrm{O}$ extracted by $\mathrm{HCl} 25 \%$ is very low (4 $\left.\mathrm{mg} 100 \mathrm{~g}^{-1}\right)$. Cation exchange capacity is relatively low $\left(16.14\right.$ me $\left.100 \mathrm{~g}^{-1}\right)$. It is closely associated with the lower availability of $\mathrm{K}(0.15$ me $\left.100 \mathrm{~g}^{-1}\right)$. The study was arranged in a completely randomized block design of one factor using 11 treatments with three replications. The study was carried out for two seasons. The treatment is the residue of control, NP, NPK, FNPK $150 \mathrm{~kg} \mathrm{ha}^{-1}$ (Formulation of NPK), FNPK $300 \mathrm{~kg} \mathrm{ha}^{-1}$, FNPK $450 \mathrm{~kg} \mathrm{ha}^{-1}$, FNPK 600 $\mathrm{kg} \mathrm{ha}^{-1}$, L $500 \mathrm{~kg} \mathrm{ha}^{-1}$ (Minerals Leucite), L 1000 $\mathrm{kg} \mathrm{ha}^{-1}, \mathrm{~L} 2000 \mathrm{~kg} \mathrm{ha}^{-1}$, L $4000 \mathrm{~kg} \mathrm{ha}^{-1}$.

The variables measured include $\mathrm{pH}$ (Potentiometric), total $\mathrm{K}(\mathrm{HCl} 25 \%)$, available $\mathrm{K}$ $\left(\mathrm{NH}_{4} \mathrm{Oac} \mathrm{pH}\right.$ 7), $\mathrm{CEC}\left(\mathrm{NH}_{4} \mathrm{Oac} \mathrm{pH}\right.$ 7), $\mathrm{K}$ uptake and the weight of dry seeds after planting. Analysis of variance ( $\mathrm{F}$ test) (5\%) and Duncan's multiple range test was also used to test the significance of treatments. In addition, the correlation and regression tests were also performed to determine the relationship among parameters.

In this study, Relative Agronomic Effectiveness (RAE) is used to assess the effectiveness of inorganic fertilizer and mineral leucite residues on corn yields. RAE is a comparison of treatment residues inorganic fertilizers NPK and mineral leucite against Standard. The following is the formula to calculate RAE:

$$
\mathrm{RAE}=\frac{(\text { yield of corn that test }- \text { control) }}{(\text { yield of corn standard }- \text { control) }} \times 100 \%
$$




\section{RESULTS}

\section{K Uptake}

Table 1 showed that inorganic fertilizer and mineral leucite residues did not significantly affect $\mathrm{K}$ uptake. FNPK $150 \mathrm{~kg} \mathrm{ha}^{-1}$ produced the highest $\mathrm{K}$ uptake $\left(3.993 \mathrm{~kg} \mathrm{ha}^{-1}\right)$ while the control had the lowest $\mathrm{K}$ uptake $\left(1.071 \mathrm{~kg} \mathrm{ha}^{-1}\right)$. FNPK $150 \mathrm{~kg} \mathrm{ha}^{-1}$ and $300 \mathrm{~kg} \mathrm{ha}^{-1}$, L $1000 \mathrm{~kg} \mathrm{ha}^{-1}$ and $2000 \mathrm{~kg} \mathrm{ha}^{-1}$ showed good results. Based on the correlation test, $\mathrm{K}$ uptake was positively correlated with total $\mathrm{K}$ total, available $\mathrm{K}$, and dry seed weight.

Table 1 also showed that inorganic fertilizer and mineral leucite residues did not significantly affect the total of $\mathrm{K}$. It means that those two factors could not increase the total of $\mathrm{K}$ in the soil. Basically, Oxisols have poor total $\mathrm{K}$, evidenced by the initial results of the analysis of total $K$ that are considered to be very low (4 $\left.\mathrm{mg} 100 \mathrm{~g}^{-1}\right)$. The total $\mathrm{K}$ was highest in FNPK 300 $\mathrm{kg} \mathrm{ha}^{-1}$ (1.169 $\mathrm{mg}^{100 \mathrm{~g}^{-1}}$ ), showing that the total $\mathrm{K}$ in the soil remains greater than other treatments. The overall total $\mathrm{K}$ residue decreased from the initial soil analysis as well as in the growing season I. Inorganic fertilizers and mineral leucite residues were not significantly $(p>0.05)$ influenced by the availability of K. Available K highest in control

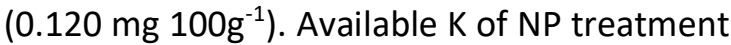
was low since there was no additional $\mathrm{K}$ fertilizer.

\section{Maize Yields}

Based on Figure 1, it is showed that the treatment of inorganic fertilizer and mineral leucite residues significantly affects the weight of dry seeds. FNPK $150-600 \mathrm{~kg} \mathrm{ha}^{-1}$ and mineral leucite residues increase the dry seed weight. It is showed that the result is not significantly different from standard NPK. The treatment of FNPK $150 \mathrm{~kg} \mathrm{ha}^{-1}$ residue showed that the highest dry seed weight is 3.78 ton $\mathrm{ha}^{-1}$ whereas the treatment of mineral leucite 4000 $\mathrm{kg} \mathrm{ha}^{-1}$ residue showed that there is a decrease in dry seed weight.

Relative agronomic effectiveness (RAE) is presented in Table 2. The treatment of $L 2,000$ $\mathrm{kg} \mathrm{ha}^{-1}$ has RAE equal to $98 \%$. It is higher than the other treatments of mineral leucite dose, but it is lower than the RAE of standard NPK. The treatment of FNPK $150-300 \mathrm{~kg} \mathrm{ha}^{-1}$ residues is effective in a technical or agronomic way, indicated by the RAE value above $100 \%$.

Table 1. The mean of K uptake (Plant), Total K (Soil), and Available K (Soil)

\begin{tabular}{|c|c|c|c|}
\hline Treatment & K Uptake (kg ha ${ }^{-1}$ ) & Total K (mg 100 $\left.\mathrm{g}^{-1}\right)$ & Available K (mg 100 $\left.{ }^{-1}\right)$ \\
\hline Control & 1.071 & 0.998 & 0.120 \\
\hline NP & 1.921 & 1.177 & 0.071 \\
\hline NPK Standard & 1.615 & 0.585 & 0.092 \\
\hline Formula NPK 150 & 3.993 & 1.012 & 0.085 \\
\hline Formula NPK 300 & 3.053 & 1.619 & 0.077 \\
\hline Formula NPK 450 & 2.767 & 0.657 & 0.092 \\
\hline Formula NPK 600 & 3.456 & 0.980 & 0.098 \\
\hline Mineral leucite 500 & 2.514 & 1.251 & 0.091 \\
\hline Mineral leucite 1000 & 2.273 & 0.585 & 0.084 \\
\hline Mineral leucite 2000 & 3.290 & 0.729 & 0.115 \\
\hline Mineral leucite 4000 & 1.258 & 1.264 & 0.076 \\
\hline
\end{tabular}




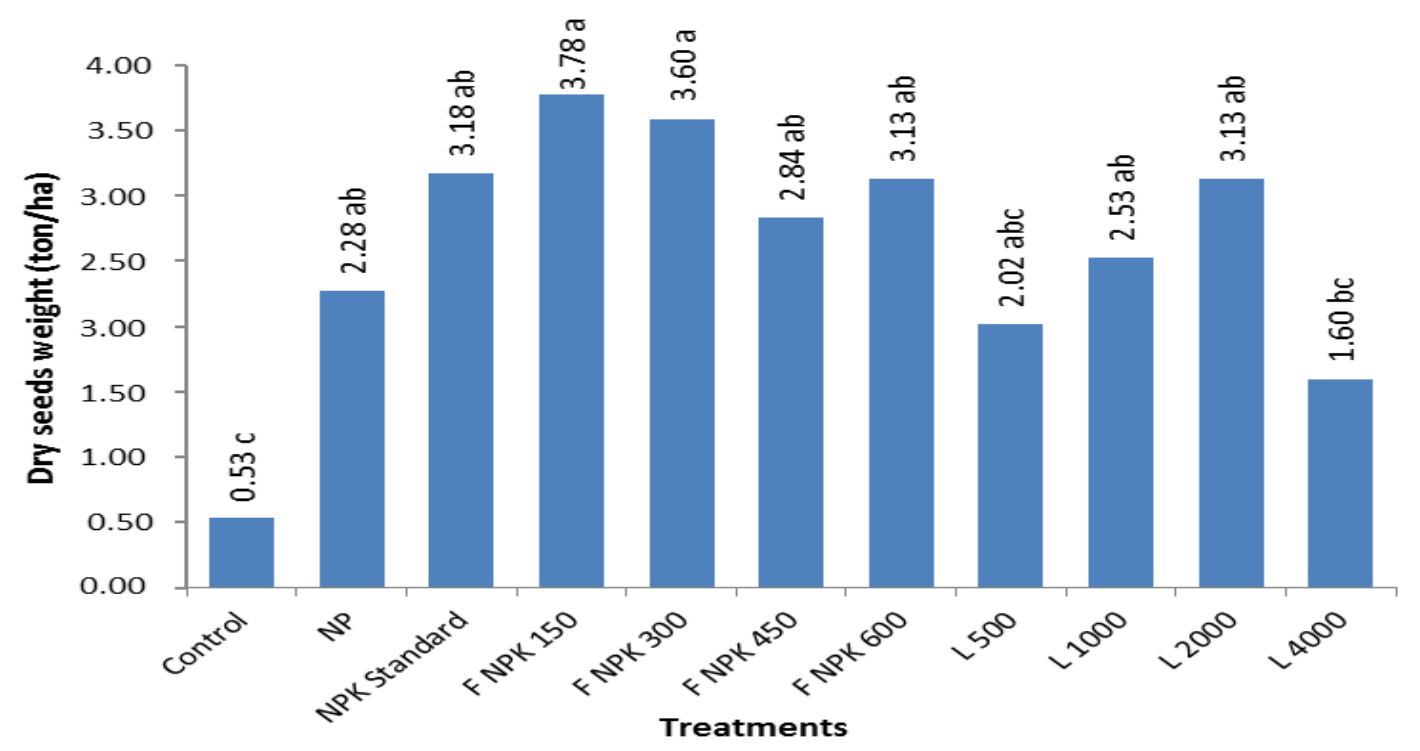

Figure 1. Effects of inorganic fertilizers and mineral leucite residues on dry seed weight.

Table 2. RAE value of the dry seeds weight

\begin{tabular}{lc}
\hline Treatment & RAE (\%) \\
\hline Control & - \\
NP & - \\
NPK Standard & 100 \\
Formula NPK 150 & 123 \\
Formula NPK 300 & 116 \\
Formula NPK 450 & 87 \\
Formula NPK 600 & 98 \\
Mineral leucite 500 & 56 \\
Mineral leucite 1000 & 75 \\
Mineral leucite 2000 & 98 \\
Mineral leucite 4000 & 40 \\
\hline
\end{tabular}

(a)

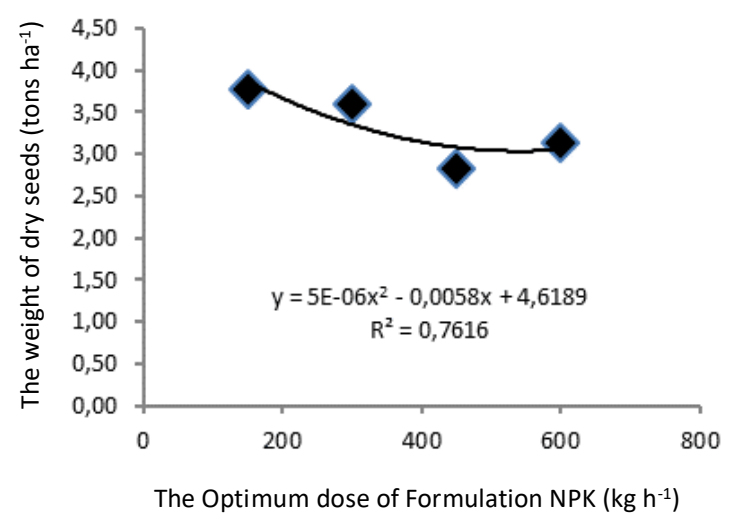

(b)

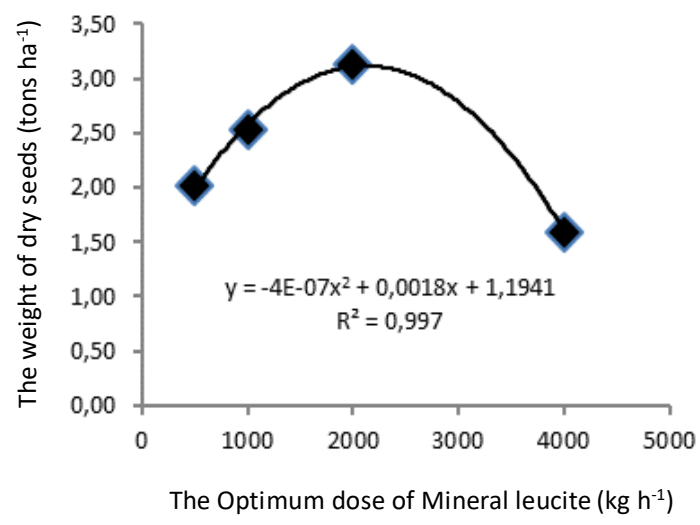

Figure 2. Regression Analysis between the dosage of FNPK (a) and mineral leucite (b) residue with dry seed weight. 
The equation of regression analysis of the FNPK residue treatment is:

$$
\begin{aligned}
& Y=-5 E-06 \times 2+0.0058 x+4.6189 \\
& \left(R^{2}=0.7616\right)
\end{aligned}
$$

The maximum dose of FNPK residue was $580 \mathrm{~kg}$ $\mathrm{ha}^{-1}$. The optimum dose (maximum dose $80 \%$ ) FNPK residue is $464 \mathrm{~kg} \mathrm{ha}^{-1}$.

The equation of regression analysis of mineral leucite residue treatment is

$$
\begin{aligned}
& Y=-4 E-07 x 2+0.0018 x+1.1941 \\
& \left(R^{2}=0.997\right)
\end{aligned}
$$

The maximum dose of mineral leucite residue is $2250 \mathrm{~kg} \mathrm{ha}^{-1}$ and the optimum dose is 1800 $\mathrm{kg} \mathrm{ha}{ }^{-1}$.

Shelled seeds are positively correlated with the $\mathrm{K}$ uptake (with a correlation coefficient $(r)=$ 0.654 ) because the element of $K$ is a catalyst agent that has a role in the metabolic processes of plants.

\section{Soil reaction $(\mathrm{pH})$ and CEC}

The results of analysis of variance of soil reaction $(\mathrm{pH})$ showed that the inorganic fertilizer and mineral leucite residues did not significantly affect soil reaction $(\mathrm{pH})(\mathrm{P}>0.05)$. The $\mathrm{pH}$ values of inorganic fertilizer and mineral leucite residues were all in the range 3.84-4.41 and did not differ statistically.

Inorganic fertilizer and mineral leucite residues were not significantly $(p>0.05)$ influenced by CEC. The control has a higher mean (15.042 me $100 \mathrm{~g}^{-1}$ ) than the other treatments. It is found that the mineral leucite of $2000 \mathrm{~kg} \mathrm{ha}^{-1}$ has the lowest CEC value of

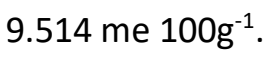

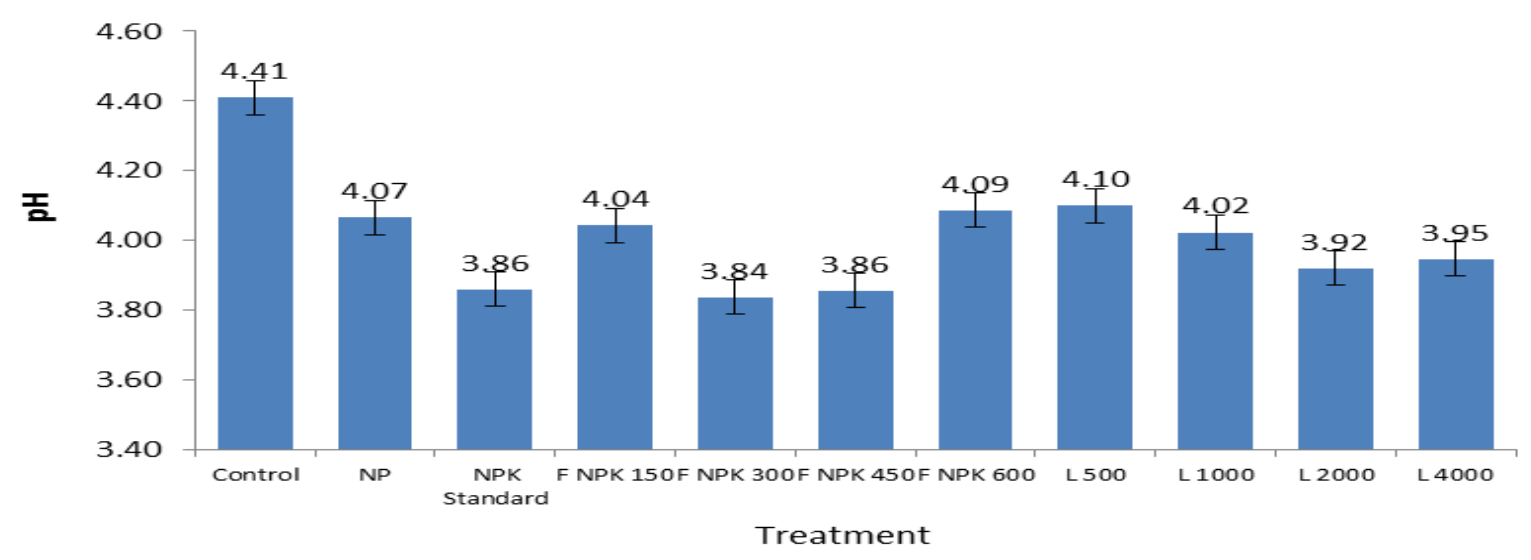

Figure 3. Effects of inorganic fertilizer and mineral leucite residues to $\mathrm{pH}$

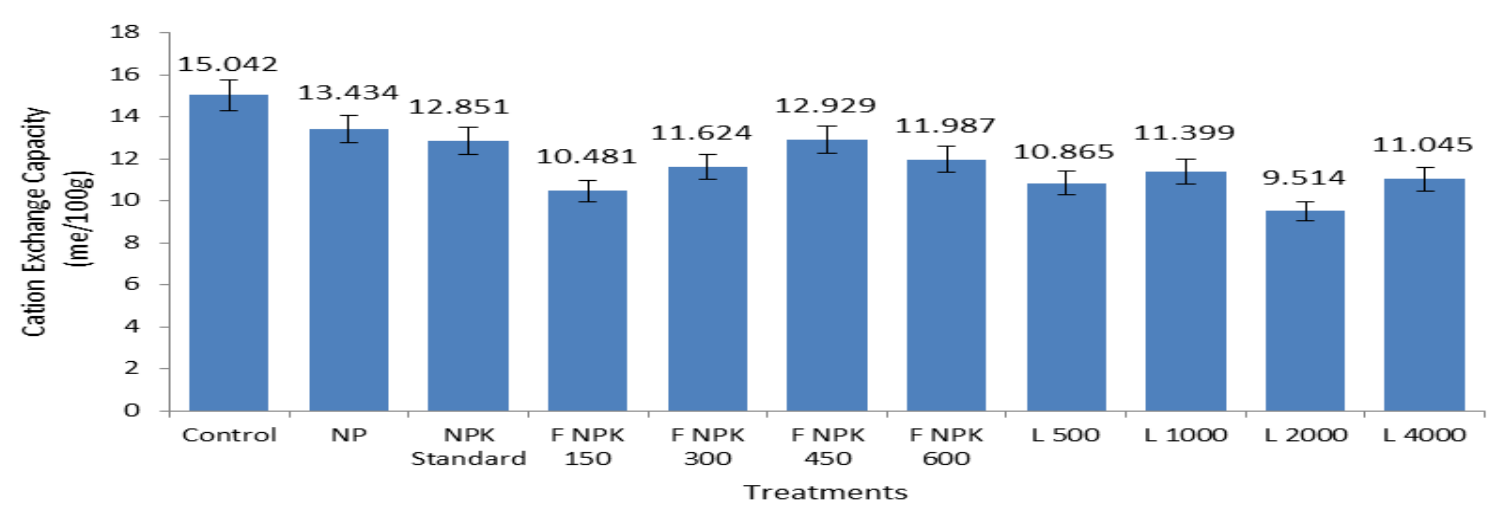

Figure 4. Effects of inorganic fertilizers and mineral leucite residues to CEC 
Hartati et al. / SAINS TANAH - Journal of Soil Science and Agroclimatology, 15(2), 2018, 120

Table 3. Correlation Analysis between variable

\begin{tabular}{lrrrrrr}
\hline & Dry Seed Weight & K Uptake & \multicolumn{1}{c}{ Total K } & Available K & \multicolumn{1}{c}{ CEC } & \multicolumn{1}{c}{ pH } \\
\hline Dry Seed Weight & 1 & $.654^{* *}$ & -.251 & -.251 & -.316 & -.311 \\
K Uptake & $.654^{* *}$ & 1 & .009 & .009 & -.184 & -.282 \\
Total K & -.251 & .009 & 1 & $1.000^{* *}$ & -.084 & .143 \\
Available K & -.251 & .009 & $1.000^{* *}$ & 1 & -.084 & .143 \\
CEC & -.316 & -.184 & -.084 & -.084 & 1 & -.067 \\
pH & -.311 & -.282 & .143 & .143 & -.067 & 1 \\
\hline
\end{tabular}

**. Correlation is significant at the 0.01 level (2-tailed)

\section{DISCUSSION}

The treatments did not affect the $\mathrm{K}$ uptake in plants (Table 1), as well as the total and available $\mathrm{K}$ in soil. This is because $\mathrm{K}$ uptake significantly correlated with total and available $K$ in the soil, in which one of them was also not affected by the treatments (Table 3 ). Total $\mathrm{K}$ highly correlated with available $\mathrm{K}$ with $\mathrm{a}$ positive correlation $(r=1)$. This shows that the increase of total $K$ will be followed by the increase of available $\mathrm{K}$. The other reason why there is no effect of the treatments is because of the characteristic of Oxisols. Sutriadi et al. (2008) state the deficiency of $\mathrm{K}$ occurs very often in Oxisols.

The reason why $\mathrm{K}$ uptake is not affected in the treatments is also that the residue does not increase $\mathrm{pH}$ (Figure 3) and CEC (Figure 4). Actually, there is no need of adding the manure and organic matter to improve soil pH and CEC. This is in line with Aprile \& Lorandi (2012) stating that the main determinants of cation exchange capacity are organic material and clay. The other opinion is also conveyed by Nurmegawati et al. (2015) saying that the low $\mathrm{pH}$ causes the loss of potassium easily through the process of leaching, leading to the deficiency of potassium.
Although the $\mathrm{K}$ uptake is not significant, it is showed that the treatment is able to increase maize yields (Fig. 1). This is in line with Rahni (2012) stating that the increase in dry seed weight was related with the ability to absorb nutrients from the soil. Fi'liyah et al. (2016) also argue that $\mathrm{K}$ uptake affects the production of corn through the synthesis of proteins in the ammonium ion metabolic processes in the $\mathrm{K}$ uptake process. Likewise, Harieni \& Minardi (2013) argued that the increase of dry weight stover crop is associated with the increase of nutrient uptake residues on treatment organic fertilizers and inorganic fertilizers.

In the first growing season, the FNPK 150 $\mathrm{kg} \mathrm{ha}^{-1}$ has the highest dry seed weight (7.28 ton $\mathrm{ha}^{-1}$ ) and RAE (130.54\%) (Hartatik et al., 2016). In the second season, the FNPK 150 residue also has the highest dry seed weight (3.78 ton ha ${ }^{-1}$ ) and RAE (123\%). It is considered to be higher than the other treatments including the NPK standard.

\section{CONCLUSION}

There was no effect of inorganic fertilizer and mineral leucite residues on the $\mathrm{K}$ uptake. On the other hands, the treatments increased maize yields through the dry seed weight. Then, having shown the relatively similar result with the NPK standard (with RAE 123\%), it is 
found that the FNPK $150 \mathrm{~kg} \mathrm{ha}^{-1}$ residue contributed a better effect on maize yields. Through looking closely at this study, it can be concluded that there are only FNPK $150 \mathrm{~kg} \mathrm{ha}^{-1}$ and $300 \mathrm{~kg} \mathrm{ha}^{-1}$ residues considered to be effective. Thus, it is recommended for farmers to mainly employ these two kinds of treatments instead of conducting the whole other treatments.

\section{REFERENCES}

Aprile, F., \& Lorandi, R. (2012). Evaluation of Cation Exchange Capacity (CEC) In Tropical Soils Using Four Different Analytical Methods. Journal of Agricultural Science, 4(6), 278-289. http://doi.org/10.5539/jas.v4n6p278

Du, Q., Zhao, X., Jiang, C., Wang, X., Han, Y., Wang, J., \& Yu, H. (2017). Effect of Potassium Deficiency on Root Growth and Nutrient Uptake in Maize (Zea mays L.). Journal of Agricultural Sciences, 8(11), 1263-1277.

http://doi.org/10.4236/as.2017.811091.

Fi'liyah, Nurjaya, \& Syekhfani. (2016). Pengaruh Pemberian Pupuk KCl terhadap N, P, K Tanah dan Serapan Tanaman pada Inceptisol untuk Tanaman Jagung di Situ Hilir, Cibungbulang, Bogor. Jurnal Tanah Dan Sumberdaya Lahan, 3(2), 329-337.

Harieni, S., \& Minardi, S. (2013). Pemanfaatan Residu Penggunaan Pupuk Organik dan Penambahan Pupuk Urea terhadap Hasil Jagung pada Lahan Sawah Bekas Galian C. Sains Tanah - Jurnal Sains Tanah Dan Agroklimatologi, 10(1), 37-44.

Hartatik, W., Anda, M., Purnomo, H., Masjkur, M., \& Setiawati, T. C. (2016). Penelitian Potensi dan Pemanfaatan Bahan Mineral sebagai Bahan Alternatif Pupuk K. Bogor (ID): Balai Penelitian Tanah.

Irawati, W., Setiawati, T. C., \& Winarso, S. (2017).
The Effect of Leucite Mineral and Potassium Solubilizing Bacteria on the Potassium Availability in Soil, Potassium Uptake and Plant Growth Of Tobacco (Nicotiana Tabacum) Besuki Na-Oogst. In Proceeding of the International Conference of FoSSA: Building of Food Sovereignty Through a Sustainable Agriculture, Challenges Toward Climate Change and Global Economic Community. Jember (ID): Universitas Jember.

Manning, D. A. (2010). Mineral Sources of Potassium for Plant Nutrition. Journal of Agronomy Sustainable, 30(2), 281-294. http://doi.org/https://doi.org/10.1051/a gro/2009023

Nurdin, N., Maspeke, P., Hahude, Z., \& Zakaria, F. (2009). Pertumbuhan dan Hasil Jagung yang dipupuk N, P, dan K pada Tanah Vertisol Isimu Utara Kabupaten Gorontalo. Jurnal Tanah Tropika, 14(1), 49-56.

Nurmegawati, Yahumri, \& Afrizon. (2015). Rekomendasi Pupuk Tanaman Jagung dan Kedelai di Kabupaten Kaur, Bengkulu. Proceeding of Seminar Nasional Masyarakat Biodiv Indonesia, 1(4), 914-917. http://doi.org/10.13057/psnmbi/m010446

Prahasta, A. (2009). Budidaya, Usaha, Pengolahan Agribisnis Jagung. Bandung (ID): Pustaka Grafika.

Prajapati, A., \& Modi, H. A. (2012). The Importance of Potassium in Plant Growth. Indian Journal of Plant Sciences, 1, 177-186.

Rahni, N. . (2012). Efek Fitohormon PGP terhadap Pertumbuhan Tanaman Jagung (Zea mays). Jurnal Agribisnis Dan Pengembangan Wilayah, 3(2), 27-35.

Setiawan, K., \& Basri, M. (2017). An Analysis of Efficiency The Production of Commodities Corn in Belu, East Nusa Tenggara, Indonesia. Journal of Environmental Science, Toxicology and Food Technology, 11(10), 64-69. 
Sutriadi, M. ., Setyorini, D., Nursyamsi, D., \& Murni, A. M. (2008). Penentuan Kebutuhan Pupuk Kalium dengan Uji KTanah untuk Tanaman Jagung di Typic Kandiudox. Jurnal Tanah Tropika, 13(3), 179-187.

http://doi.org/https://doi.org/10.5400/jt s.2008.v13i3.179-187

Turner, I. G. (2009). Ceramics and Glasses. In Roger Narayan (Eds.), Biomedical Materials. (pp. 3-39). United State of
America, USA: University of North

Carolina, Chapel Hill. Reviews, http://doi.org/10.1007/978-0-387-

84872-3

Yousaf, M., Li, J., Lu, J., Ren, T., Cong, R., Fahad, S., \& Li, X. (2017). Effects of Fertilization on Crop Production and NutrientSupplying Capacity under Rice-Oilseed Rape Rotation System. Scientific Reports, 7, 1-9. http://doi.org/10.1038/s41598017-01412-0 